\title{
Citric Acid-induced Long Chain Formation of Streptococcus sp.
}

\author{
Susumu Ito, Tohru Kobayashi, Masahiro SaItoH \\ and Toshiki MORICHI* \\ Tochigi Research Laboratories, Kao Corporation, Ichikaimachi, \\ Hagagun, Tochigi 321-34, Japan \\ * National Institute of Animal Industry, Tsukuba, Norindanchi, \\ P.O. Box 5, Ibaraki 305, Japan
}

Received November 25, 1983

\begin{abstract}
In the presence of citrate, citrate-fermenting Streptococcus sp. KSM-1106 and KSM-1112 grew in long chains with innumerable cells. Divalent cations, such as $\mathrm{Mn}^{2+}$ and $\mathrm{Ca}^{2+}$, arrested the chain elongation. The results with citrate-negative and citrate-resistant variants suggested the involvement of citrate in the cell separation system. A dechaining activity, which was inhibited by citrate, could be demonstrated in the cell extract of strain KSM-1106. Such a special effect of citrate was not observed on the growth of strains of other lactic streptococci examined.
\end{abstract}

The streptococci have been reported to grow as pairs or short chains, and in some cultures as long chains. ${ }^{1)}$ Among them, group N streptococci occupy an important position as lactic starters for characteristic flavor production in dairy products. However, the morphological knowledge of the organisms under different cultural conditions has not yet been accumulated.

In a rapid communication, ${ }^{2)}$ we reported that in the presence of citrate, group $\mathrm{N}$ Streptococcus sp. KSM-1106 and KSM-1112 grew as long chains with innumerable cells. To clarify the mechanism of this function of citrate, we have obtained citrate-resistant and citrate-negative mutants from Streptococcus sp. KSM-1106. In this paper, we describe more details concerning the long chain formation induced by citrate. This abnormal morphology is suggested to result from inhibition by citrate of a dechaining activity in the cells.

\section{MATERIALS AND METHODS}

Bacteria. All bacterial strains used in this study were group N streptococci. Streptococcus sp. KSM-1106 was isolated from a commercial cream by $\mathrm{S}$. I., and
Streptococcus sp. KSM-1112 from a lactic starter by T. M. These isolates were identified as the intermediate type of lactic streptococci, which were neither typical $S$. cremoris nor S. lactis (unpublished data). The other streptococci used included 12 strains belonging to the following species: 5 strains of $S$. cremoris; 4 strains of $S$. lactis; and 3 strains of $S$. diacetilactis. The strains were kept at $4^{\circ} \mathrm{C}$ by periodical transfer in reconstituted skim milk (Difco) in order to maintain their lactose fermentability (Lac) and protease activity (Prt). The citrate-utilizing ability (Cit) was checked periodically by growth on the citrate agar plates recommended by Kempler and McKay. ${ }^{3)}$

Media. The standard medium contained the following ingredients ( $\mathrm{g} /$ liter): glucose, 10 ; polypeptone, 10; yeast extract, 0.5 ; and distilled water ${ }^{2}$; the $\mathrm{pH}$ level was adjusted to 6.8 with $\mathrm{NaOH}$. The citrate medium was this medium containing disodium citrate at varied concentrations. These media were supplemented with filter-sterilized inorganic ions, organic acids, amino acids and antibiotics, as required.

Cultural conditions and measurements of growth. The cultures were grown anaerobically in flasks or test tubes and inoculated with $1 \%$ of the same preculture. Anaerobic growth was attained in containers which were filled with growth medium up to the necks. They were incubated at $26^{\circ} \mathrm{C}$, unless otherwise stated, and at intervals samples were taken into $3.0-\mathrm{ml}$ cuvettes, and the absorbance at $590 \mathrm{~nm}\left(A_{590}\right)$ was measured on a Hitachi 101 spectrophotometer. 
Detection and determination of diacetyl. The medium for diacetyl production was reconstituted skim milk fortified with $5 \mathrm{~mm}$ citrate. Ten-milliliter portions of the medium were placed in test tubes $(23$ by $200 \mathrm{~mm}$ ) and incubated aerobically at $30^{\circ} \mathrm{C}$ on a test tube rotary shaker (300 rpm) with $1 \%$ of the preculture. After $16 \mathrm{hr}$ of incubation, the diacetyl formed was checked by its color reaction with creatine. $^{4)}$ The quantitative determination was made according to Iwaida et al. ${ }^{5)}$

Isolation of mutants. The gene coding for the Cit phenotype was plasmid-linked in our strains (unpublished data). The Cit of KSM-1106 was highly unstable and readily cured when the cells were transplanted successively 10 times in a stab agar medium ${ }^{6)}$ at $30^{\circ} \mathrm{C}$. After the curing, $\mathrm{Cit}^{-}$colonies were incubated in reconstituted skim milk at $26^{\circ} \mathrm{C}$ for 2 days and then plated on the citrate agar plates. A $\mathrm{Cit}^{-}$colony, designated $\mathrm{KSM}-1106 \mathrm{C}^{-}$, was purified from the white-colony isolates and its relevant phenotype was $\mathrm{Lac}^{+} \mathrm{Prt}^{+} \mathrm{Cit}^{-}$. The strain $\mathrm{KSM}-1106 \mathrm{C}^{-}$did not produce diacetyl from citrate but could do so from oxalacetate and pyruvate, suggesting that this variant lacked a citrate permease. ${ }^{7)}$

Growth of the parental KSM-1106 strain completely ceased in $40 \mathrm{mM}$ citrate medium. Its citrate-resistant $\left(\mathrm{Cit}^{\mathrm{R}}\right)$ mutant, capable of growing in excess citrate, was obtained as follows. The resting cell suspensions from an exponential culture in the standard medium were treated with $\mathrm{N}$ methyl- $N^{\prime}$-nitro- $N$-nitrosoguanidine $(10 \mu \mathrm{g} / \mathrm{ml})$ for $90 \mathrm{~min}$ at $30^{\circ} \mathrm{C}$ with gentle mechanical agitation. The treated cells were diluted with sterile deionized water 10 -fold and immediately transferred to reconstituted skim milk, and incubation was continued with standing at $26^{\circ} \mathrm{C}$ until the culture coagulated. An aliquot $(0.1 \mathrm{ml})$ was then resuspended in $150 \mathrm{~mm}$ citrate medium $(100 \mathrm{ml})$. After incubation of $2 \sim 4$ days at $26^{\circ} \mathrm{C}$, the culture with appropriate dilutions was plated onto the citrate agar plates and then incubated anaerobically. The blue colonies formed $^{3)}$ were selected and purified 3 times. By this procedure, strain $\mathrm{Cit}^{\mathrm{R}} \mathrm{KSM}-1106 \mathrm{C}^{\mathrm{R}}\left(\mathrm{Lac}^{+} \mathrm{Prt}^{+} \mathrm{Cit}^{+}\right)$was isolated.

In the skim milk culture, strain $\mathrm{KSM}^{-1106 \mathrm{C}^{-}}$did not form diacetyl but strain KSM-1106C ${ }^{\mathrm{R}}$ formed it at the same level as observed with the parent $(9.8 \sim 14.3 \mu \mathrm{g} / \mathrm{ml})$.

Determination of chain length. The cell number in each chain was counted microscopically at a magnification of 1,000 , as described previously. ${ }^{2)}$

Preparation and assay of dechaining activity. The cell extracts containing "dechaining activity" were prepared from the parent and the $\mathrm{Cit}^{\mathrm{R}}$ mutant grown on the standard medium $(100 \mathrm{ml})$ at $26^{\circ} \mathrm{C}$ for $16 \mathrm{hr}$. The cells were collected and standardized with $50 \mathrm{~mm}$ potassium phosphate buffer (pH 7.0) to an $A_{590}$ of $0.5 \sim 0.6$ on 50 -fold dilution. The cell suspension was disrupted by sonication (Ultrasonic Co., Ltd., UK) below $4^{\circ} \mathrm{C}$ for $20 \mathrm{~min}$ and then centrifuged at $12,000 \times g$ for $10 \mathrm{~min}$. The resulting supernatant was used as the cell extract. The culture filtrate was obtained from the spent medium, using a millipore filter $(0.22 \mu \mathrm{m}$ pore size).

The substrate for the enzyme was the chained cells of parental KSM-1106 collected from a 36-hr-old culture containing $10 \mathrm{~mm}$ citrate. The cells were washed twice

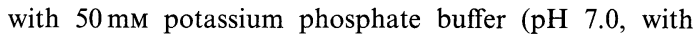
$20 \mu \mathrm{g} / \mathrm{ml}$ of chloramphenicol), diluted with the same buffer to $6 \sim 7$ units of $A_{590}$ on 50-fold dilution, and kept at about $4{ }^{\circ} \mathrm{C}$ until use. The reaction mixture of $2.0-\mathrm{ml}$ final volume contained: $0.5 \mathrm{ml}$ of $0.1 \mathrm{M}$ potassium phosphate buffer ( $\mathrm{pH} \mathrm{7.0)}, 0.5 \mathrm{ml}$ of the substrae, and $0.4 \mathrm{ml}$ of the cell extract $(0.6 \mathrm{mg}$ protein) or the culture filtrate $(0.2 \mathrm{mg}$ protein). The reaction was started by the addition of the substrate, and after $2 \mathrm{hr}$ of incubation at $30^{\circ} \mathrm{C}$ the number of cells per chain was counted.

The chained cells were dissolved in $1.0 \mathrm{~N} \mathrm{NaOH}$, and protein was assayed by the method of Lowry et al. ${ }^{8)}$

Chemicals. Unless otherwise specified, the reagents used were from Wako Pure Chemicals and were certified reagent grade. Sodium ethylenediamine tetraacetate (EDTA, 99\% pure) and sodium aluminum silicate (Zeolite 4A) were purchased from Sigma and Henkel, respectively. Antibiotics such as D-cycloserine (Sigma), bacitracin (P-L Biochemicals), ampicillin (Sigma), cephazorin (Fujisawa), vancomycin Shionogi), and ristocetin (Sigma) were obtained from the sources in parentheses.

\section{RESULTS}

Effects of organic acids and inorganic chelaters

Supplementation with various organic acids (15 mM) and chelaters (EDTA, $0.25 \mathrm{mM}$; Zeolite 4A, $120 \mathrm{mg} / \mathrm{ml}$; and tripolyphosphate, $20 \mathrm{mg} / \mathrm{ml}$ ) allowed the growth of Streptococcus sp. KSM-1106 for $16 \mathrm{hr}$. The amount of growth $\left(A_{590}\right)$ and the chain length (number of cells/chain) were 0.52 and $4.2 \pm 0.4$ for the control culture (no addition) and 0.79 and innumerable for citrate. The others examined (oxalacetate, succinate, malate, cis-aconitate, trans-aconitate, fumarate, DL-isocitrate, tartarate, itaconate, pyruvate, EDTA, Zeolite 4A, and tripolyphosphate) had almost no significant effect.

\section{Effects of culture conditions}

The chain length of strain KSM-1106 did not change with growth between 13.4 and $29.7^{\circ} \mathrm{C}\left(0.21 \sim 0.99\right.$ of $A_{590} / 16 \mathrm{hr}, 3.5 \pm 0.2 \sim$ $3.8 \pm 0.6$ cells/chain) in a temperature gradient 
incubator. At $37.9^{\circ} \mathrm{C}$, an upper limit for growth, the chain length was somewhat lengthened $\left(0.29 \sim 0.40\right.$ of $A_{590}, 6.0 \pm 0.5 \sim$ $8.1 \pm 0.4$ cells/chain). Initial $\mathrm{pH}$ from 4.5 to 7.7 of the growth medium also did not cause the long chain formation. Nor did essentially any sugars, added in place of glucose, such as fructose, galactose, lactose, maltose, trehalose, or salicin. In $15 \mathrm{~mm}$ citrate medium, this strain grew as long chains with innumerable cells, independent of the added sugars (data not shown).

\section{Growth with additives affecting cell wall synthesis}

In the standard medium, all of the antibiotics tested (D-cycloserine, bacitracin, ampicillin, cephazorin, vancomycin, and ristocetin), inhibitors of cell wall synthesis, did not affect the growth of strain KSM-1106. Glycine and/or isoleucine, known to alter the bacterial cell wall,9) also had no effect. In $5 \mathrm{~mm}$ citrate medium, this strain grew long chains with $28 \pm 2.6$ cells/chain, but with the addition of the building blocks of the bacterial cell wall, such as lysine, diaminopimelic acid, glutamic acid, alanyl-alanine, ( $N$-acetyl)glucosamine, and so on, did not revert to the normal shortchained growth.

\section{Function of inorganic ions}

Various cations except for $\mathrm{Al}^{3+}, \mathrm{Co}^{2+}$, $\mathrm{Na}^{+}, \mathrm{K}^{+}$, and $\mathrm{NH}_{4}^{+}$interrupted the long chain formation of strains KSM-1106 and KSM1112 , induced by $15 \mathrm{~mm}$ citrate (Table I). A tendency to dechain the cells was in order of $\mathrm{Mn}^{2+}>\mathrm{Ca}^{2+}>\mathrm{Mg}^{2+}>\mathrm{Fe}^{2+}>\mathrm{Zn}^{2+}$ for both strains. In the $15 \mathrm{~mm}$ citrate medium, the shortest chain length of strain KSM-1106 was observed at $5 \mathrm{~mm}$ for $\mathrm{Mn}^{2+}$ and at $15 \mathrm{~mm}$ for $\mathrm{Ca}^{2+}$, respectively (data not shown).

\section{Growth characteristics of Cit variants}

To gain further insights into the mechanism of the long chain formation, we obtained $\mathrm{Cit}^{-}$ and $\mathrm{Cit}^{\mathrm{R}}$ variants from strain KSM-1106 (see Materials AND Methods).

When citrate was raised from zero to $15 \mathrm{~mm}$,
Table I. Prevention of the Chained Growth BY INORGANIC IONS

\begin{tabular}{|c|c|c|}
\hline \multirow{2}{*}{$\begin{array}{c}\text { Inorganic } \\
\text { ion added } \\
\quad(5 \mathrm{mM})\end{array}$} & \multicolumn{2}{|c|}{ No. of cells/chain/16 hr ${ }^{a}$} \\
\hline & Strain KSM-1106 & Strain KSM-1112 \\
\hline No addition & $(0.96)$ & $(1.12)$ \\
\hline $\mathrm{Al}^{3+}$ & $\infty \quad(0.91)$ & $(0.95)$ \\
\hline $\mathrm{Fe}^{3+}$ & $26 \pm 1.6(0.96)$ & $\infty \quad(1.10)$ \\
\hline $\mathrm{Fe}^{2+}$ & $14 \pm 0.9(0.92)$ & $43 \pm 2.8(1.10)$ \\
\hline $\mathrm{Mn}^{2+}$ & $5.6 \pm 0.5(1.12)$ & $4.7 \pm 0.4(1.10)$ \\
\hline & $6.4 \pm 0.4(1.10)^{b}$ & $5.8 \pm 0.4(1.13)^{b}$ \\
\hline $\mathrm{Ca}^{2+}$ & $8.8 \pm 0.6(1.12)$ & $10 \pm 1.7(1.12)$ \\
\hline & $10 \pm 0.6(1.11)^{b}$ & $8.2 \pm 0.7(1.12)^{b}$ \\
\hline $\mathrm{Zn}^{2+}$ & $25 \pm 2.0(0.77)$ & $28 \pm 2.1(0.81)$ \\
\hline $\mathrm{Mg}^{2+}$ & $12 \pm 0.8(1.10)$ & $13 \pm 1.1(1.10)$ \\
\hline $\mathrm{Co}^{2+}$ & $\infty \quad(0.26)$ & $\infty \quad(0.22)$ \\
\hline $\mathrm{NH}_{4}^{+}$ & $(0.95)$ & (1.09) \\
\hline $\mathrm{Na}^{+}$ & $(0.95)$ & $(0.95)$ \\
\hline $\mathrm{K}^{+}$ & $(0.95)$ & $(1.10)$ \\
\hline
\end{tabular}

a The organisms were grown in the growth medium containing $15 \mathrm{~mm}$ citrate. Numbers in parentheses indicate the amount of growth in terms of $A_{590}$ reading. The symbol $\infty$ means the long chains with innumerable cells.

$b$ The ion was autoclaved together with other components of the growth medium.

growth of the parent and KSM-1106C strains was stimulated up to $130 \%$ of the level of the control cultures (no citrate), but above $15 \mathrm{~mm}$ it was retarded (Fig. 1A). More than $40 \mathrm{~mm}$ concentration of citrate completely inhibited the growth of the both strains, even after further incubation for 3 days. In contrast, strain KSM-1106C $\mathrm{C}^{\mathrm{R}}$ could grow in $220 \mathrm{mM}$ citrate medium. The amount of growth of the $\mathrm{Cit}^{\mathrm{R}}$ strain was consistently higher between 5 and $170 \mathrm{~mm}$ citrate: the maximum stimulation was observed at $30 \sim 50 \mathrm{~mm}(160 \%$ of the control level). However, any significant difference in growth rates for susceptibility to EDTA was not observed among the parent, KSM-1106C ${ }^{-}$, and KSM-1106C $\mathrm{C}^{\mathrm{R}}$ strains (Fig. 1B). Furthermore, the susceptibilities to tripolyphosphate and Zeolite were the same among these strains as that to EDTA.
Effect of citrate concentration on the chain length

The parent and $\mathrm{KSM}-1106 \mathrm{C}^{-}$strains grew 


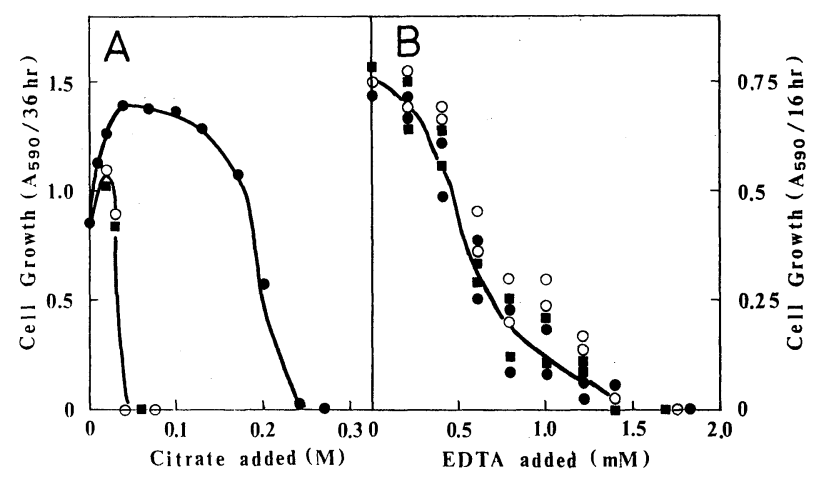

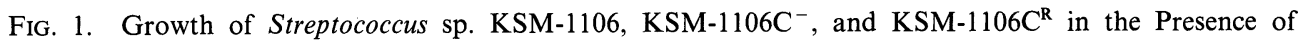
Citrate (A) and EDTA (B).

Results with the parent, $\mathrm{O}$; KSM-1106C $\mathrm{C}^{-}, \mathbf{\square}$; KSM-1106C $\mathrm{C}^{\mathrm{R}}$, - EDTA was separately autoclaved and added to other components of the growth medium just before inoculation.

as long chains with increasing cell number with increases in citrate concentration (Fig. 2). When the citrate concentration was brought to $15 \mathrm{~mm}$, the chains became tangled clumps, in which several hundred cells in each chain were frequently observed. In contrast, strain KSM-1106C ${ }^{\mathrm{R}}$ grew as short chains over the citrate concentration between zero and $40 \mathrm{~mm}$ citrate $(2.0 \pm 0.3 \sim 5.8 \pm 0.2$ cells/chain $)$, and above $40 \mathrm{~mm}$ abruptly as long chains.

\section{Chain length during growth}

At intervals from zero to $33 \mathrm{hr}$, the growth characteristics were followed for KSM-1106 and its derivatives in $5 \mathrm{~mm}$ citrate medium (Fig. 3). In the citrate medium, the parent (and KSM-1106C ${ }^{-}$) strain grew in chains of increasing cell numbers with incubation time. In contrast, strain $\mathrm{KSM}-1106 \mathrm{C}^{\mathrm{R}}$ was found to grow as very short chains during the incubation time. Among these strains, significant differences in patterns of $\mathrm{pH}$ change and amount of growth were not observed.

\section{Involvement of an enzyme in separation of chained cells}

It was suggested that an enzyme responsible for the separation of cells was inhibited by citrate. Detection of the enzyme was demonstrated using KSM-1106 and KSM-1106C ${ }^{\mathrm{R}}$ strains. A typical result is summarized in Table

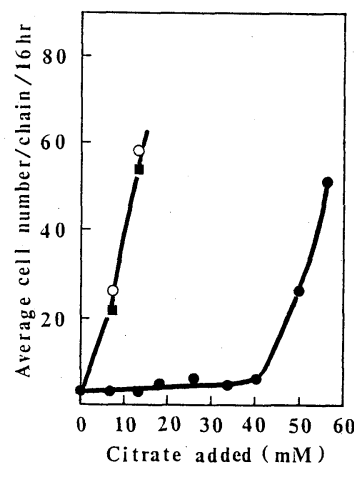

FIG. 2. Chain Length of Streptococcus sp. KSM-1106, KSM-1106C ${ }^{-}$, and KSM-1106C ${ }^{\mathrm{R}}$ as a Function of Citrate Concentration.

The symbols were as used in Fig. 1.

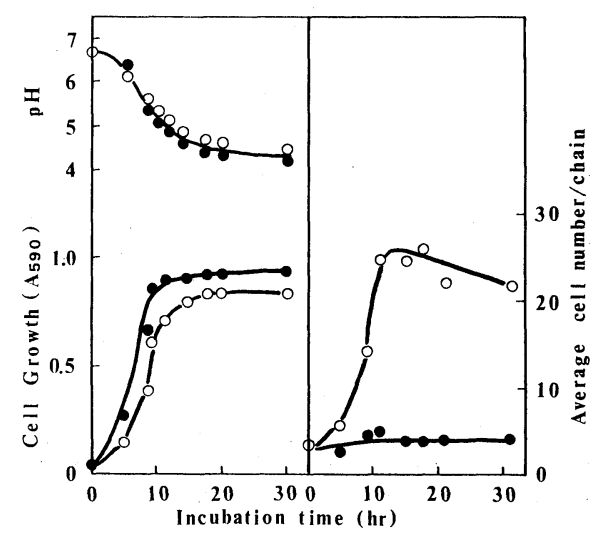

FIG. 3. Growth and Chain Length of the Parental KSM$1106(\bigcirc)$ and $\mathrm{KSM}-1106 \mathrm{C}^{\mathrm{R}}(\mathrm{O})$ in the Presence of $5 \mathrm{mM}$ Citrate. 
Table II. Dechaining Activity of Streptococcus sp. KSM-1106 AND KSM-1106C ${ }^{\mathrm{R}}$

Experimental procedures are given in MATERIALS AND METHODS. The chained cells of parental strain KSM-1106 (9.9 $\mathrm{mg}$ cell protein) were used as substrate. The boiled enzyme fractions were obtained by heating the native fractios at $100^{\circ} \mathrm{C}$ for $10 \mathrm{~min}$. Concentration of citrate added was $45 \mathrm{~mm}$.

\begin{tabular}{lcc}
\hline \multicolumn{1}{c}{ Enzyme fraction } & $\begin{array}{c}\text { Chain length } \\
\text { after } 2 \mathrm{hr} \\
\text { (No. of } \\
\text { cells/chain) }\end{array}$ & $\begin{array}{c}\text { Protein } \\
\text { released } \\
(\mathrm{mg} / \mathrm{ml})\end{array}$ \\
\hline Zero time & $58 \pm 3.3$ & 0.01 \\
No addition & $38 \pm 3.1$ & 0.18 \\
-KSM-1106- & & \\
Cell extract & $11 \pm 0.4$ & 1.22 \\
Boiled extract & $36 \pm 1.7$ & 0.10 \\
Cell extract plus citrate & $31 \pm 3.2$ & 0.39 \\
Culture filtrate & $39 \pm 1.4$ & 0.09 \\
-KSM-1106C ${ }^{\mathrm{R}}-$ & & \\
Cell extract & $9 \pm 0.8$ & 1.03 \\
Cell extract plus citrate & $10 \pm 0.4$ & 0.98 \\
Culture filtrate & $40 \pm 3.1$ & 0.07 \\
\hline
\end{tabular}

II, although the experimental data fluctuated frequently. Only upon addition of the cell extracts from both strains, a marked reduction of chain length occurred, accompanied by protein leakage into the reaction mixtures. The dechaining activity of the parent was lost significantly by boiling, indicating a typical enzymatic characteristic. There occurred some chain splitting without the cell extract, suggesting that the long-chained growth was due to a difficulty in the enzymatic function. In fact, it was found that citrate markedly inhibited the dechaining activity in the extract of the parent. On the other hand, the dechaining activity in the extract of the $\mathrm{Cit}^{\mathrm{R}}$ strain was active even in the presence of citrate. Culture filtrates did not contain such dechaining activities.

\section{Chain length of various streptococci with citrate}

The growth responses on citrate (15 and $30 \mathrm{~mm}$ ) were examined for various lactic streptococci including $S$. lactis (4 strains), $S$. cremoris (5 strains), and $S$. diacetilactis (3 strains). Unlike our strains, these organisms grew as the normal short chains in the citrate medi- um, regardless of whether the growth was inhibited or stimulated.

\section{DISCUSSION}

The streptococci characteristically tend to grow as pairs or short chains, but in chains of variable length under different growth conditions. ${ }^{10)}$ With strains of $S$. cremoris, Whitehead and Hunter ${ }^{11)}$ observed so-called "involution" forms on cultivation at $37^{\circ} \mathrm{C}$, which had very long chains of flattened cocci. The long-chained cultures of $S$. cremoris and $S$. lactis were isolated from growth which formed in orifices of medium inlet tubes of chemostats. ${ }^{12)}$ Dring and Hurst ${ }^{13)}$ also found that penicillin elongated $S$. lactis cells into rodshaped Gram-negative ones.

In this paper, we reported that citrate specifically induced the long chain formation of Streptococcus sp. KSM-1106 and KSM1112. It is of interest that a dechaining activity, whose function was greatly inhibited by citrate, was demonstrated in the cell extract of our strains. Therefore, this abnormal morphology may be related to inhibition by citrate of the dechaining activity. In fact, inhibition of dechaining activities have frequently been reported to induce the long chain formation with strains of Streptococcus ${ }^{14 \sim 18)}$ and other organisms. ${ }^{19 \sim 21)}$

When incubated with the cell extract, the chained cells of our strain released a considerable amount of protein (13 to $26 \%$ of the total in the cells, Table II). This suggests that a concomitant lytic enzyme (lysozyme-like autolysin ${ }^{22)}$ ) present in the extract may interfere with the measurement of the dechaining activity. Therefore, it is still unclear whether "dechaining enzyme" detected in our strain is functionally analogous to the autolysins or not. In this connection, Shockman ${ }^{22}$ has emphasized the importance of lysozyme-like autolysin in cell division and separation, in addition to the function during lysis. Fein and Rogers $^{23)}$ also presented more direct evidence for the mechanism of long chain formation of bacterial cells, using an autolysin-deficient 
Bacillus subtilis.

Divalent cations, such as $\mathrm{Mn}^{2+}$ and $\mathrm{Ca}^{2+}$, prevented the long chain formation by citrate of our strains. This indicates that these cations are concerned with the ability of the organisms to separate into short chains in some way for normal growth. There is a possibility that the effects of the cations might be explained on the basis of the chelating action of citrate. In fact, bacterial cell separation has been reported to require divalent cations. ${ }^{24,25)}$ However, the mechanism of the special effect of citrate on our strains cannot readily be explained by its chelating activity with the essential divalent cations, because stronger chelaters such as EDTA, tripolyphosphate, and Zeolite, were irrelevant to the abnormal morphology. It appears, therefore, that the dechaining enzyme in our strains has a specific binding or affinity site for citrate. In these strains, the essential role of the ions for the enzyme is thought to be nullified in some way by excess citrate, and hence the long chain formation resulted. Therefore, it seems likely that the dechaining enzyme of the $\mathrm{Cit}^{\mathrm{R}}$ mutant is one that was altered genetically to a lower affinity to citrate. However, the physiological meaning of the presence of the citrate-binding site remains unclear.

It has been suggested that citrate permease of lactic streptococci is located in the cytoplasmic membrane. ${ }^{26,27)}$ From the $\mathrm{Cit}^{-}$mutant experiments, the dechaining enzyme in our strains may be located in the cytoplasmic membrane or in the periplasmic gap of the cells. We are now engaging in the purification and characterization of this enzyme. We believe that further studies on our strains will provide a clue to explain the complex mechanisms of the division and separation of microorganisms.

Acknowledgments. We thank Professor S. Takao of Hokkaido University for providing us with many strains of Streptococcus. The technical assistance of Miss Y. Akiyama is gratefully acknowledged.

\section{REFERENCES}

1) M. Teuber and A. Geis, "The Prokaryotes," Vol. 2, ed. by M. P. Starr, H. Stolp, H. G. Truper, A. Balows and H. G. Schlegel, Springer-Verlag, New York, 1981, p. 1614.

2) S. Ito, S. Inoue, M. Saitoh and T. Morichi, Biotechnol. Lett., 4, 709 (1982).

3) G. M. Kempler and L. L. Mckay, Appl. Environ. Microbiol., 39, 926 (1980).

4) B. W. Hammer, J. Dairy Sci., 18, 579 (1935).

5) M. Iwaida, C. Shibuya and T. Tsugo, Shokuhin Kogyo Gakkaishi, 10, 408 (1963).

6) K. Kawai, S. Yashima, Y. Okami and Y. Sasaki, J. Gen. Appl. Microbiol., 17, 51 (1971).

7) R. J. Harvey and E. B. Collins, J. Bacteriol., 82, 954 (1961).

8) O. H. Lowry, N. J. Rosebrough, A. L. Farr and R. J. Randall, J. Biol. Chem., 193, 265 (1951).

9) S. Miyashiro, H. Enei, K. Takinami, Y. Hirose, T. Tsuchida and S. Udaka, Agric. Biol. Chem., 44, 2297 (1980).

10) J. M. Sherman and W. R. Albus, J. Bacteriol., 3, 153 (1918).

11) H. R. Whitehead and G. J. E. Hunter, J. Gen. Microbiol., 3, 43 (1949).

12) I. J. McDonald, Can. J. Microbiol., 17, 897 (1971).

13) G. J. Dring and A. Hurst, J. Gen. Microbiol., 55, 185 (1969).

14) B. Reiter and J. D. Oram, J. Dairy Res., 29, 63 (1962).

15) R. D. Ekstedt and G. H. Stollerman, J. Exp. Med., 112, 671 (1960).

16) M. L. Higgins, H. M. Pooley and G. D. Shockman, J. Bacteriol., 103, 504 (1970).

17) I. Lominski, J. Cameron and G. Wyllie, Nature, 181, 1477 (1958).

18) J. W. Soper and C. G. Winter, Biochim. Biophys. Acta, 297, 333 (1973).

19) A. N. Chatterjee, D. Mirelman, H. J. Singer and J. T. Park, J. Bacteriol., 100, 846 (1969).

20) D. P. Fan, J. Bacteriol., 103, 494 (1970).

21) A. Tomasz, Proc. Natl. Acad. Sci. U.S.A., 59, 86 (1969).

22) J. D. Shockman, Bacteriol. Rev., 29, 345 (1965).

23) J. E. Fein and H. J. Rogers, J. Bacteriol., 127, 1427 (1976).

24) M. Webb, J. Gen. Microbiol., 3, 410 (1949).

25) M. Kojima, S. Suda, S. Hatta, K. Hamada and A. Suganuma, J. Bacteriol., 104, 1010 (1970).

26) E. B. Collins and R. J. Harvey, J. Dairy Sci., 45, 32 (1962).

27) G. M. Kempler and L. L. McKay, Appl. Environ. Microbiol., 37, 316 (1979). 